\title{
The Public Domain
}




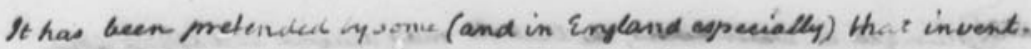

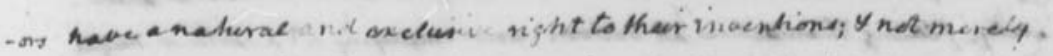

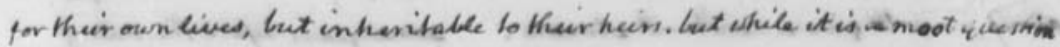
whether the onfin of any kind of property is devived from natiene at all, it would be simpular to admut a nituriel, and wen an heredidasy nigh to

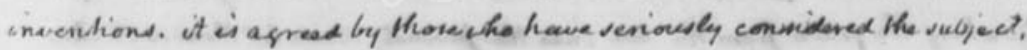
that no individual has, of natural ripht, a seprarate properta in an acre f' land, for invlanes . Gy an uncivorsal law indecel, whateven, whather fixed or moverible, belongs to all mevi equally ande incommon, it the proporty, for the

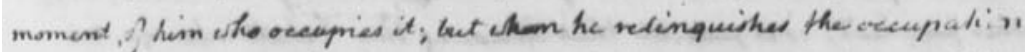

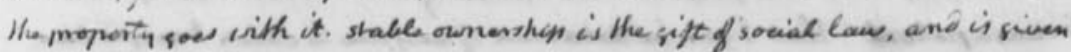

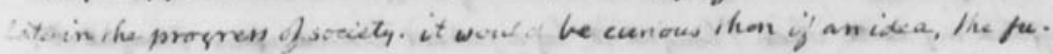

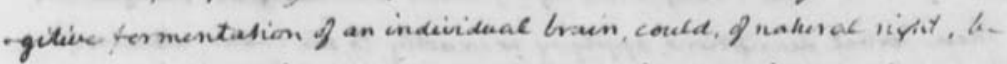
claimed in exelesice and shble proprerty. if natase has ma.le eny, one

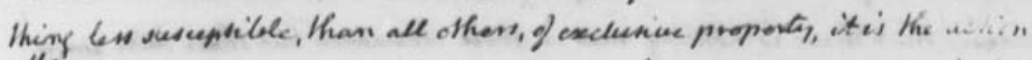

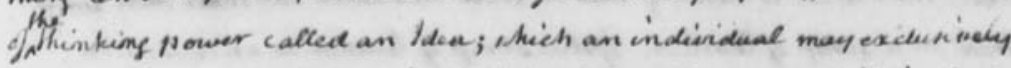

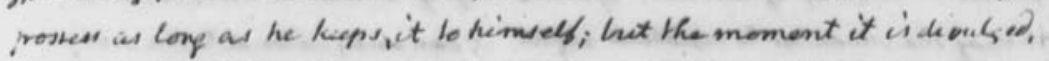

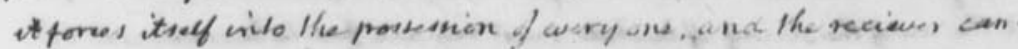

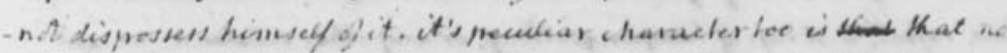

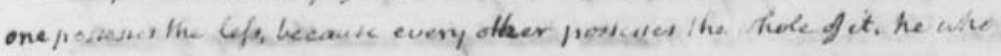

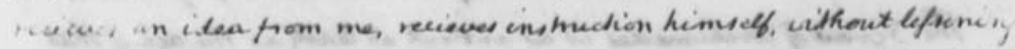
mene; is he whe light his taper at mine, recieves light withant daik. - suing me. That ideas should freely spread from one to and thav ous

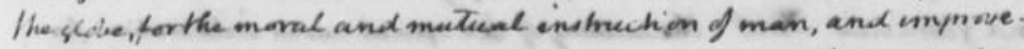

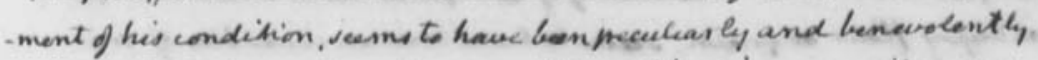
devined h, nature, when she mude them, like fire, expankible over allspace, without lestening their densita, in any point; and like the air in thich we breathe, molse, and have our phyoical being, incapable of confinement, or exclunice appropmiatien, inentions then cannot in

Thomas Jefferson to Isaac McPherson, August I3, I813, p. 6. 


\section{James Boyle}
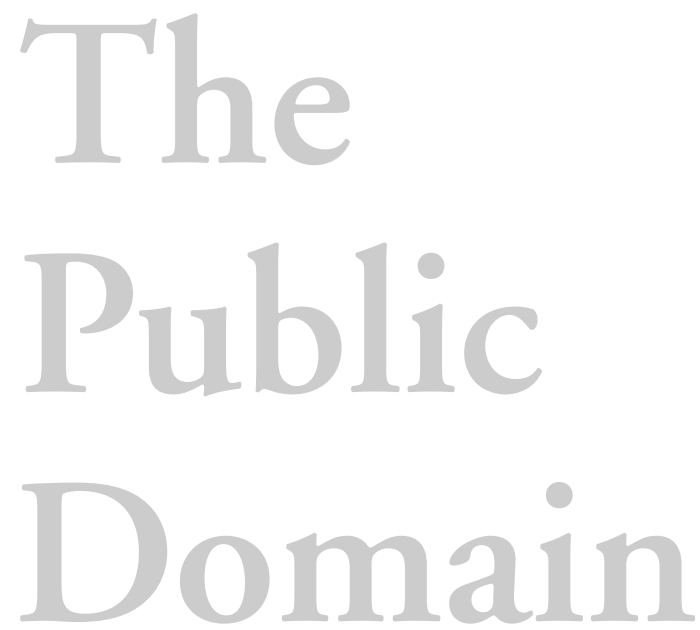

Enclosing the Commons of the Mind

Yale University Press

New Haven \& London 
A Caravan book. For more information, visit www.caravanbooks.org.

Copyright () 2008 by James Boyle. All rights reserved.

The author has made an online version of this work available under a Creative Commons Attribution-Noncommercial-Share Alike 3.o License. It can be accessed through the author's website at http://james-boyle.com.

Subject to the exception immediately following, this book may not be reproduced, in whole or in part, including illustrations, in any form (beyond that copying permitted by Sections 107 and Io8 of the U.S. Copyright Law and except by reviewers for the public press), without written permission from the publishers.

Printed in the United States of America.

ISBN: 978-0-300-13740-8

Library of Congress Control Number: 2008932282

A catalogue record for this book is available from the British Library.

This paper meets the requirements of ANSI/NISO Z39.48-1992 (Permanence of Paper). It contains 30 percent postconsumer waste (PCW) and is certified by the Forest Stewardship Council (FSC) 